\title{
Labechia carbonaria Smith 1932 in the Early Carboniferous of England; affinity, palaeogeographic position and implications for the geological history of stromatoporoid-type sponges
}

Stephen Kershaw ${ }^{1,2^{*}}$ and Consuelo Sendino ${ }^{2}$

\begin{abstract}
Stromatoporoid sponges were very abundant during the middle Palaeozoic Era and are thought to disappear at the end of the Devonian Period in the Hangenberg Crisis. However, there are records of organisms with stromatoporoid-type structure in Carboniferous strata, the subject of this study. The Viséan fossil Labechia carbonaria Smith 1932 has been discussed previously in literature and its affinity has not been confirmed. In this study, the type material of L. carbonaria collected from the middle part of the Frizington Limestone Formation (previously called Seventh Limestone), Holkerian Substage, stored in the Natural History Museum (London, UK) and British Geological Survey (Keyworth, UK) was re-examined. The Holkerian Substage, in which L. carbonaria was found, lies between ca 335-339 Ma, and the Frizington Limestone Formation ranges from topmost Arundian to upper Holkerian, so middle Frizington Limestone Formation is likely approximately $337 \mathrm{Ma}$. L. carbonaria comprises thick long pillars connected by thin curved cyst plates consistent with the structure of the stromatoporoid genus Labechia. However, a common opinion is that L. carbonaria fossils may be mistaken for fragments of rugose corals, but there are problems with assigning it to the Rugosa. In vertical section (VS) L. carbonaria could be mistaken for a transverse section (TS) of a Carboniferous rugose coral. However, in TS L. carbonaria shows the rounded cross sections of stromatoporoid pillars. If it was a coral, septal sheets of the VS of a coral should be seen. For a rugose affinity to still apply, a coral structure would have to be composed of free trabeculae, but these are not known after the middle of the Devonian Period; there are no corals of Early Carboniferous age with the structure of $L$. carbonaria. Another interpretation, that L. carbonaria is a chaetetid, is discounted because it lacks calicles and is very different in structure from chaetetids. We conclude that $L$. carbonaria is a stromatoporoid. Because the beginning of the Carboniferous Period was ca $359 \mathrm{Ma}$, stromatoporoids thus occur approximately 22 million years after their purported disappearance at the end-Devonian Hangenberg Crisis. L. carbonaria, together with other rare occurrences in Carboniferous strata of stromatoporoid-form sponges Newellia mira (Newell) in USA, and uncertain taxa Komia Korde and Palaeoaplysina Krottow that have been attributed to stromatoporoids by some authors, (Continued on next page)
\end{abstract}

\footnotetext{
* Correspondence: Stephen.kershaw@brunel.ac.uk

'Department of Life Sciences, Brunel University London, Kingston Lane, Uxbridge UB8 3PH, UK

${ }^{2}$ Department of Earth Sciences, Natural History Museum, Cromwell Road, London SW7 5BD, UK
}

\section{Springer Open}

๑ The Author(s). 2020 Open Access This article is licensed under a Creative Commons Attribution 4.0 International License, which permits use, sharing, adaptation, distribution and reproduction in any medium or format, as long as you give appropriate credit to the original author(s) and the source, provide a link to the Creative Commons licence, and indicate if changes were made. The images or other third party material in this article are included in the article's Creative Commons licence, unless indicated otherwise in a credit line to the material. If material is not included in the article's Creative Commons licence and your intended use is not permitted by statutory regulation or exceeds the permitted use, you will need to obtain permission directly from the copyright holder. To view a copy of this licence, visit http://creativecommons.org/licenses/by/4.0/. 


\begin{abstract}
(Continued from previous page)
supports some published views that end-Devonian stromatoporoid extinction may not have been as final as is traditionally interpreted. Thus Mesozoic stromatoporoids may represent resurgence of sponge lineages that survived the late Palaeozoic, perhaps in uncalcified form. Palaeogeographically, during the Early Carboniferous, the UK was positioned in low latitudes and in a central location of global distribution of reefal buildups during the late Palaeozoic continental assembly towards Pangaea. Thus it is curious that L. carbonaria is found in only one place; future search may determine its true palaeographic distribution, with potential reconsideration of the extinction of stromatoporoids at the end of the Devonian Period.
\end{abstract}

Keywords: Stromatoporoids, Holkerian, Viséan, Carboniferous, Rugosa, Labechia carbonaria, Labechia conferta

\section{Introduction}

Stromatoporoids are hypercalcified sponges that are abundant from middle Ordovician time to the end of the Devonian Period (Wilson 1975, chapter 4). They are generally considered to have become extinct at the Hangenberg Crisis at the end of Devonian time and thus to be effectively missing from the later parts of the Palaeozoic rock record (Stearn 2015a, b). Thus of great interest is the discovery of a stromatoporoid-type calcified sponge, Labechia carbonaria Smith, 1932 in Lower Carboniferous strata of northern England (Smith 1932) that led to a summary discussion by Stearn (2015a) about whether Palaeozoic stromatoporoids did indeed become extinct at the Hangenberg Crisis. Mistiaen $(1984,1994)$ proposed that stromatoporoids did not become extinct but simply lost their ability to calcify. Thus it is possible that $L$. carbonaria is a rare example of retention of calcified structure, or that this organism survived in such low numbers that fossil finds are unlikely. However, Sokolov (1955) reinterpreted L. carbonaria as a chaetetid sponge, a common taxon in the Carboniferous. Stearn (2015a) drew attention to the problem of verification of the affinity of $L$. carbonaria; his discussion noted the issue of discriminating between broken pieces of rugose corals and stromatoporoid-type sponges and ended with a statement that there is no certainty that $L$. carbonaria is a stromatoporoid and thus no confirmed stromatoporoids occur after the end of the Devonian Period.

In this study, re-examination of the holotype material collected by Smith (1932), deposited in the Natural History Museum, London (NHM) and the British Geological Survey, Keyworth, Nottinghamshire (BGS) aims: a) to resolve the affinity of L. carbonaria and b) to develop the wider question about the geological history of stromatoporoids and potential palaeographic distribution after the end-Devonian event.

\section{Material and methods}

Samples of Labechia carbonaria assembled by Smith were divided between collections of the NHM and BGS, so that the NHM holds five thin sections and the BGS holds eighteen hand specimens and nine thin sections. The holotype and paratype material is held by the BGS, detailed later. Given the precious resource of a limited number of specimens, no further preparations were requested and illustrations presented here are directly from existing hand specimens and thin sections. The key hand specimens and thin sections were photographed. Although all the material was examined, we illustrate only the best samples that reveal the structure very well. $L$. carbonaria samples of Smith's (1932) collections were derived from four locations distributed in two closely located areas in the modern Cumbria County in northwest England: Hale and Frizington (Fig. 1b). Near Hale (about $10 \mathrm{~km}$ ESE of the coastal town of Whitehaven), each of three boreholes remarkably yielded samples of $L$. carbonaria from the middle part of the Seventh Limestone (Smith 1932), renamed the Frizington Limestone Formation (FLF) of the Great Scar Limestone Group (see Dean et al. 2011, page 108). The FLF ranges from latest Arundian to upper Holkerian Substages (upper Viséan Stage), which places the middle FLF at approximately the middle Holkerian Substage (see Fig. 2). Smith (1932, p. 24) stated that the $L$. carbonaria samples were found over a vertical range of $25 \mathrm{ft}(7.6 \mathrm{~m})$ at a range of depths from 1049 to $1676 \mathrm{ft}(320-511 \mathrm{~m})$ below surface. Two boreholes were spaced 1100 yards $(1006 \mathrm{~m})$ apart along a line NE-SW on the ground and the third borehole was 200 yards $(183 \mathrm{~m})$ ESE of the southwestern borehole. Thus at Hale, the $L$. carbonaria material occurred in two areas (NE and SW) approximately $1 \mathrm{~km}$ apart. At Frizington Park, approximately $10 \mathrm{~km} \mathrm{~N}$ of Hale (Fig. 1b), further material comes from outcrops correlated with the Hale boreholes. Thus, the samples were recovered from a small area of west Cumbria, within one limestone formation. Illustrations of a sample of another Labechia taxon, the abundant and well-known Labechia conferta (Lonsdale), from the Silurian of England are included in this study, together with comparative illustration of an Early Carboniferous chaetetid from Wales, and a representative selection of hand specimens of British Early Carboniferous rugose corals.

\section{Geological setting and stratigraphy}

British Lower Carboniferous rocks occur in a complex palaeogeography of shelves and basins, with small blocks 


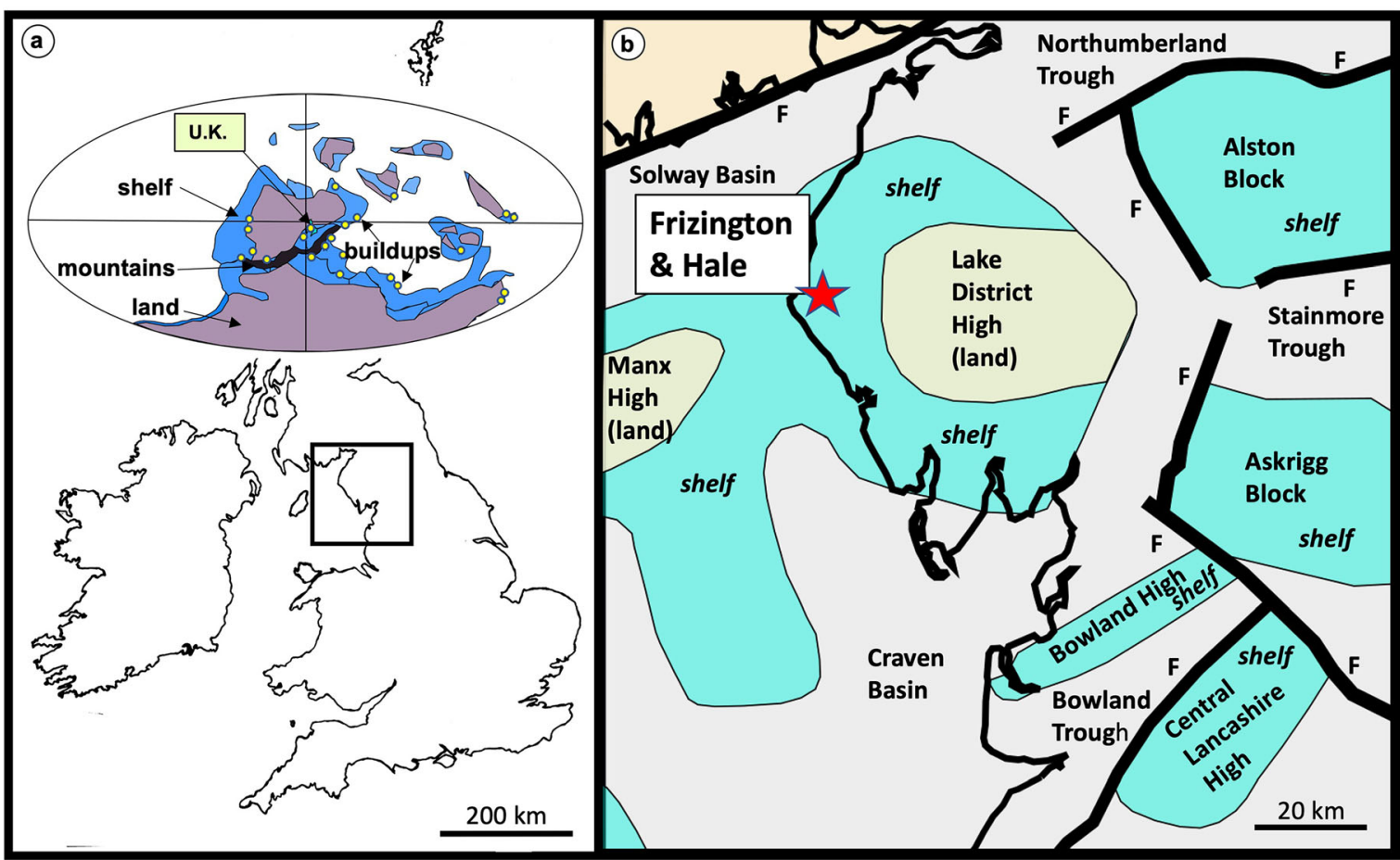

Fig. 1 Localities and Early Carboniferous palaeogeographic setting. a Map of British Isles showing location of more detailed map in b. Inset shows global Early Carboniferous palaeogeography, the location of the UK and the distribution of Early Carboniferous reefal buildups (yellow dots) from Webb (2002); b Regional palaeogeographic setting of northern England showing sample locations for Labechia carbonaria assembled by Smith (1932), after Waters et al. (2009)

in a tensional tectonic setting north of the Variscan Orogen (Woodcock and Strachan 2012). Labechia carbonaria samples were collected from marine shelf limestones west of the interpreted island (Waters et al. 2009) of the Lake District High (Fig. 1b). Figure 1a illustrates a summary global palaeogeography during the Early Carboniferous, that also includes the global distribution of reefal buildups at that time (from Webb 2002). It is clear that the UK lay within the tropical latitudes and regionally is surrounded by sites with buildups in shelf settings. Nevertheless there is no evidence that the L. carbonaria fossils came from buildups.

The Seventh Limestone (=Frizington Limestone Formation) is listed in the BGS online Lexicon of strata (BGS Lexicon of strata) as located in the Seminula $S_{2}$ Biozone, Holkerian substage, within the Viséan Stage of the Mississippian Subsystem (Fig. 2), matching Smith's (1932) account of the horizon from which the samples were collected. The Frizington Limestone Formation is a thinly bedded limestone interbedded with siltstones and some shale. The lower part of the formation bears evidence of intertidal settings with rhizoliths, fenestral limestones and hummocky cross-bedded sandstones. The limestones are bioclastic packstones to grainstones and contain layers of lithostrotionid corals (Dean et al. 2011, page 109). Altogether this is a very shallow marine to intertidal sequence and it may be presumed that $L$. carbonaria specimens lived in fully marine conditions. The chronostratigraphic age of the sequence, given by Waters et al. (2009) indicates that the Holkerian strata were deposited between approximately 335-339 Ma, and so the middle Holkerian rocks (the horizon of the Seventh Limestone) are approximately $337 \mathrm{Ma}$, thus about 22 million years younger than the Devonian-Carboniferous boundary ( $c a 359 \mathrm{Ma}$ ). That boundary has the Hangenberg Crisis at which the Palaeozoic stromatoporoids died out (Stearn 2015a).

\section{Results: description of Labechia carbonaria}

The structure of L. carbonaria Smith (1932) is shown in Figs. 3, 4, 5, 6, 7, 8 and 9 of this study, confirming Smith's (1932) description that it is a dome-shaped fossil. Figures 3 and 6 illustrate its features in three dimensions. In vertical section (VS) it comprises vertically-orientated stout pillars that developed normal (=perpendicular) to the growth surface, together with interconnecting cyst plates. In transverse section (TS) the pillars are revealed as approximately rounded structures that are commonly amalgamated with neighbours (Figs. 7 and 8). No alignment of pillars is observed in TS, they are haphazardly organised but form a more-or- 


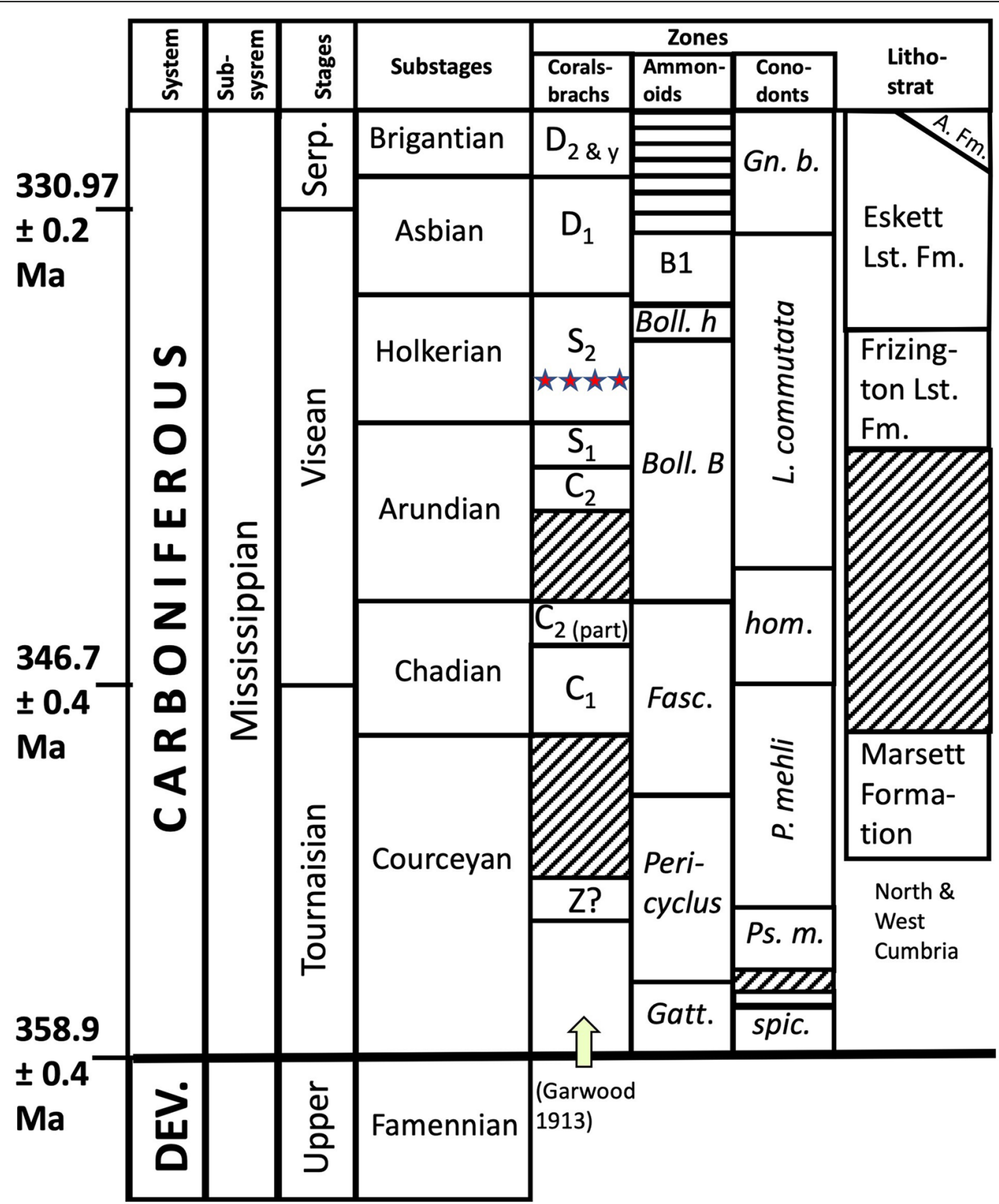

Fig. 2 Stratigraphy of the Lower Carboniferous sequence in England, showing the Devonian/Carboniferous boundary and the approximate horizon in the Frizington Limestone Formation (=Seventh Limestone of older terminology) that yielded Labechia carbonaria samples (red stars) illustrated in this study. After Waters et al. (2009). Selected biozones based on the older coral-brachiopod zones of Garwood (1913) and current conodont and ammonoid zones (from Dean et al. 2011, Table 2) are shown; Lithostratigraphy for north and west Cumbria areas relevant to this study is from Dean et al. (2011), Fig. 7); see Dean et al. (2011) for explanation of all abbreviations in this figure

less evenly spaced system (Fig. 7). There is no evidence of organisation into septa.

Figure 3 illustrates a vertical section of a dome-shaped hand specimen (paratype sample UKBGS.GSM51517). This is an incomplete specimen, measuring $80 \mathrm{~mm}$ in widest horizontal dimension and $100 \mathrm{~mm}$ high; thus its complete dimensions are unknown. Prominent thick pillars, a prime component of its architecture, are clearly visible in this cut face. Figure 4 shows a transverse section (holotype sample UKBGS.GSM51516), showing the pillars in transverse section in the centre, changing to oblique section at the margins, as expected in cut section through a dome-shaped structure. The base and top of the specimens are not preserved so the relationship between the $L$. carbonaria and its substrate is not known. However, sediment attached to the sides of the holotype and paratype (Figs. 3 and 4) is a wackestone, indicating growth in a relatively low energy 


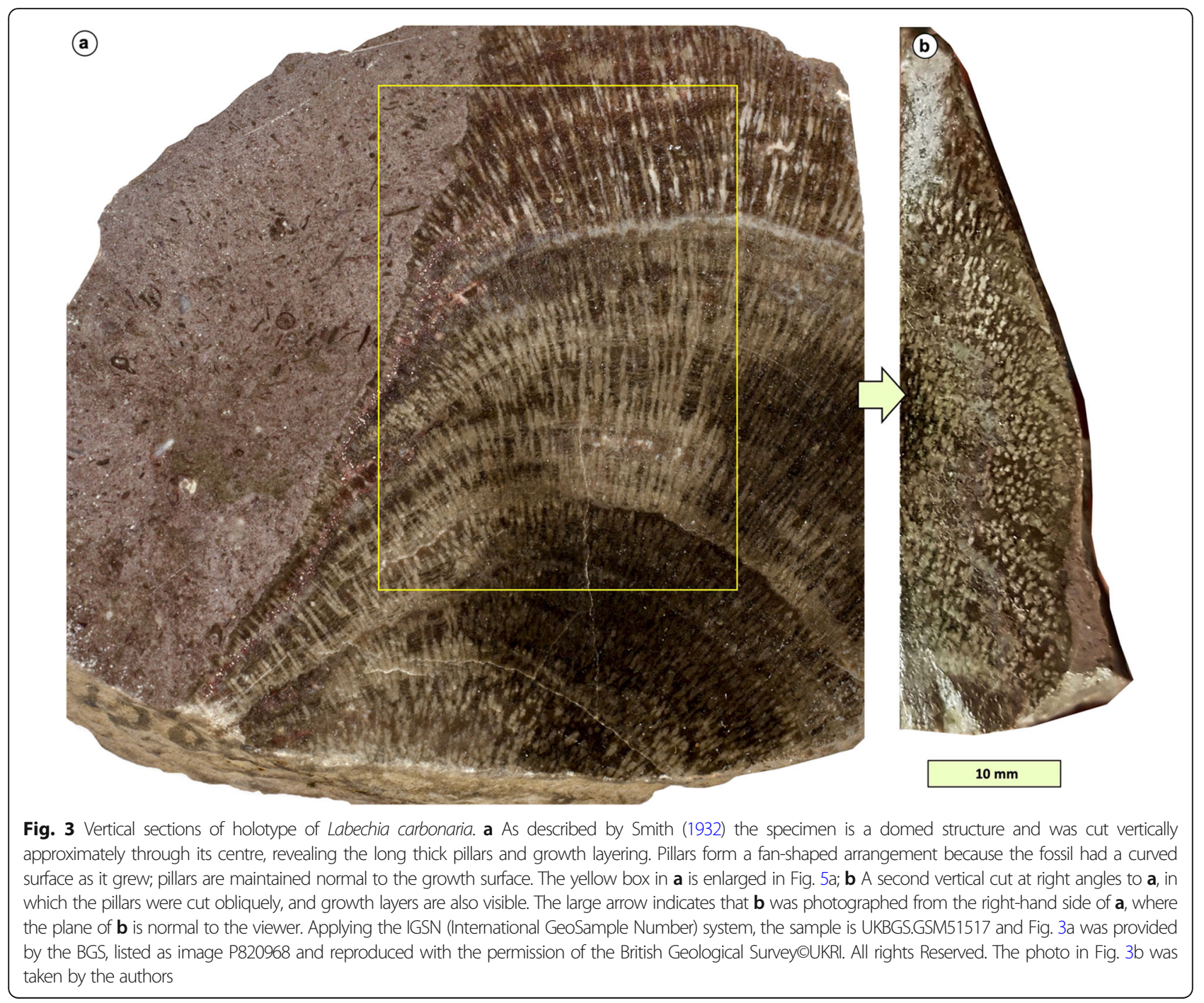

environment, which is a typical facies for stromatoporoids (and corals and chaetetids). Nevertheless, as mentioned above, description of the Frizington Limestone Formation (Dean et al. 2011) indicated packstones and grainstones are significant components of the rock, evidence of higher energies. However, the precise conditions in which the L. carbonaria organisms lived may or may not have been higher energies. Overall they lived in shallow marine conditions which may be presumed were subject to varying energy conditions. Enlargements of the polished surface of the two samples are shown in Fig. 5, where pillars and connecting cysts, and growth layers are all visible. Figure 6 reveals the structure in three dimensions, where the pillars are seen in both vertical and transverse section on the polished surfaces of the same specimen. In thin sections, details of the architecture are revealed. Figure 7 demonstrates the arrangement of pillars and cyst plate structure; pillars are apparently branched although it is not completely clear if this is a feature of slightly oblique vertical section through a three-dimensional arrangement of closelyspaced pillars, some of which might be simply touching neighbours. Pillars are approximately circular and range $0.3-0.5 \mathrm{~mm}$ diameter. Pillar lengths cannot be determined because they are not parallel to the plane of section in the available thin sections; however, minimum pillar lengths shown in Fig. 7 are up to $4 \mathrm{~mm}$; it is possible that individual pillars are several centimetres long. Cyst plates are flat to concave and convex in vertical section, $c a 0.02-0.03 \mathrm{~mm}$ thick and extend between pillars. Figure 8 shows detail of the skeletal structure in a thicker portion of the thin sections where the microstructure is visible. Figure 9 shows the structure in vertical section at the margins of the thin section where the structure is thinner, in hand-ground thin sections. Thinning at the margins allows the architecture to be viewed at different thicknesses and thus more fully observed. In Fig. 9 the pervasive recrystallisation that affects all 


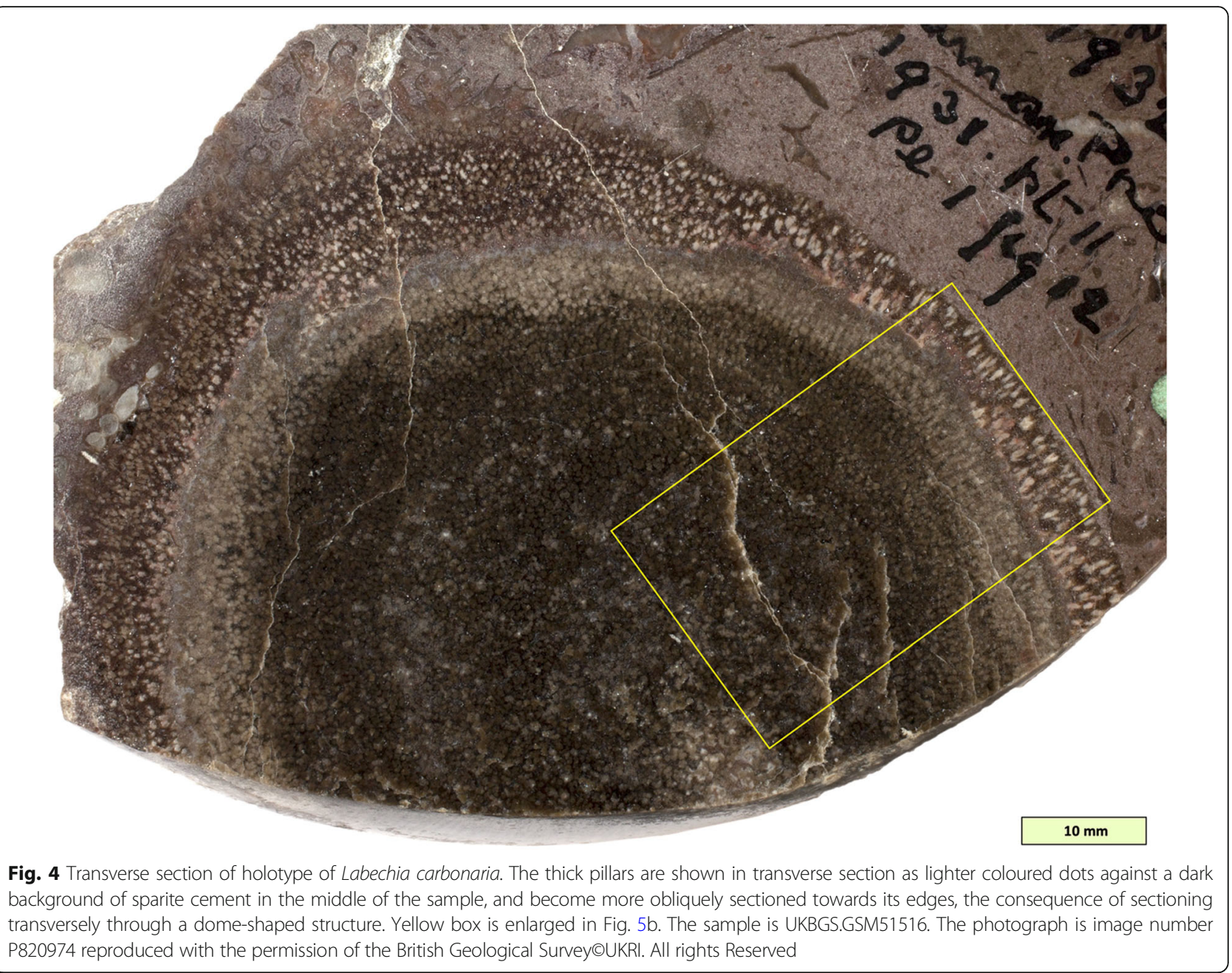

stromatoporoids is revealed and is best seen in the thinner marginal part of the section on the left side of the photographs.

The structure of $L$. carbonaria is compared with a $\mathrm{Si}$ lurian example of the Palaeozoic stromatoporoid Labechia conferta (Lonsdale) (Figs. 10, 11), from the Much Wenlock Limestone Formation at Wren's Nest, Dudley, stored in the Sedgwick Museum of Earth Sciences, Cambridge, England. Both taxa are composed of prominent stout pillars and cyst plates. Both also have indistinct downward-pointing chevron-like fibrous structure, but in $L$. conferta the pillars also have a curved internal layering that resembles a cone-in-cone architecture (Webby 2015, p. 720 and Fig. 392) and the cyst plates are shorter, as convex-up plates connecting the pillars. Smith (1932, p. 30) also noted that L. carbonaria is a domical shaped fossil and has branched pillars, whereas L. conferta is a laminar shaped fossil and its pillars do not branch; these differences are visible in Figs. 3, 4, 5, $6,7,8,9,10$ and 11 of this paper.
Comparisons of $L$. carbonaria with chaetetids and rugose corals are presented in Figs. 12 and 13. Chaetetids are profusely illustrated in literature (e.g. West 2011) and the senior author of this study holds a collection of chaetetids from UK and USA; Fig. 12 is a representative example, from the UK and shows the distinct calicle structure of chaetetids in VS and TS. Figure 13 shows a selection of rugose corals from the Lower Carboniferous of England, illustrating their complexity of structure, for comparison with $L$. carbonaria.

\section{Discussion}

The two key aspects of the Labechia carbonaria fossils in the Lower Carboniferous of northern England are highlighted in this discussion: a) the affinity of L. carbonaria in comparison with stromatoporoids, chaetetids and rugose corals; and b) the implications of the affinity of $L$. carbonaria, and the central location of its occurrence in Early Carboniferous palaeogeography, for the geological history of stromatoporoids (Fig. 14). 

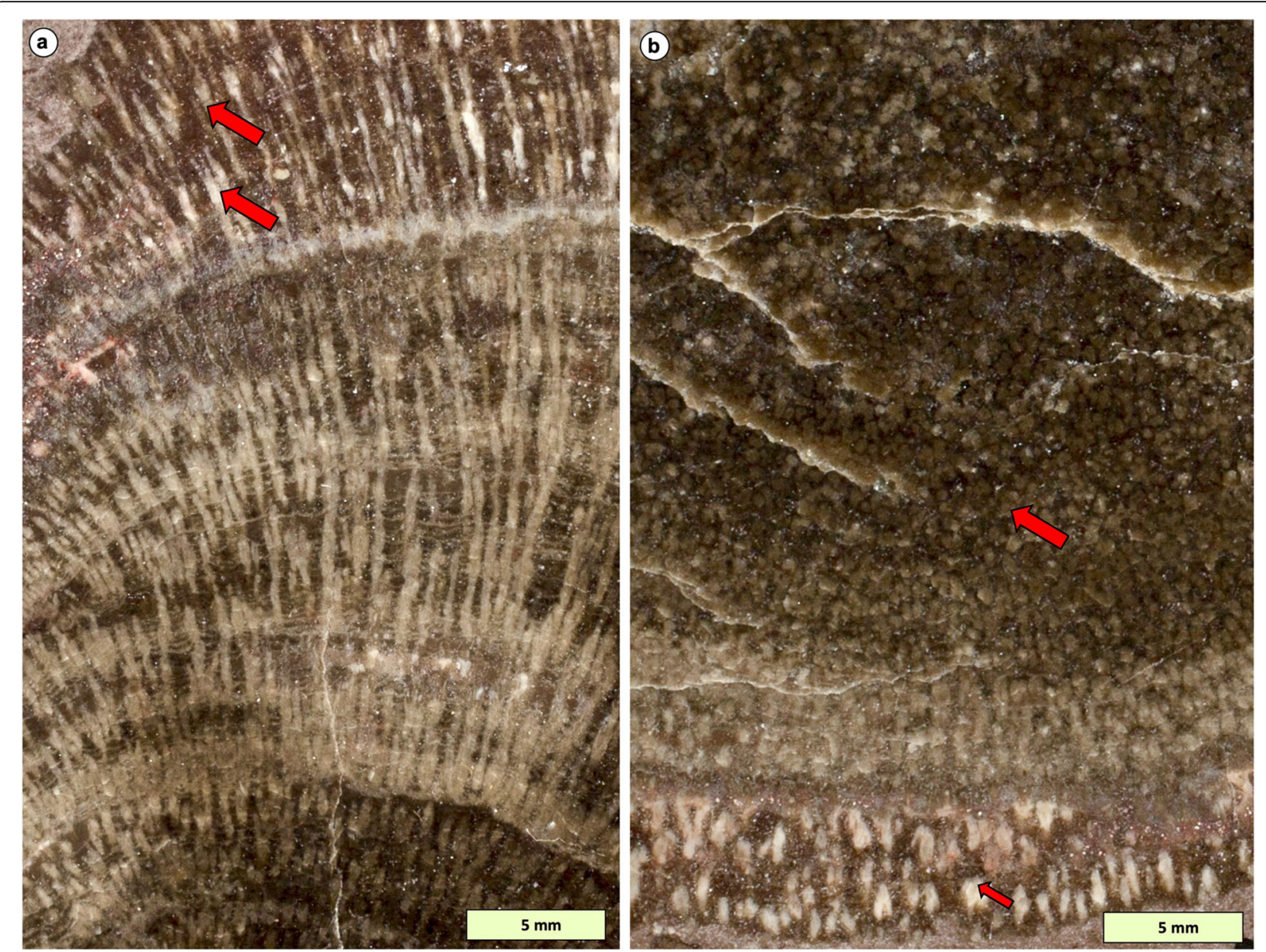

Fig. 5 a Enlargement of the yellow box in Fig. 3 showing the structure of L. carbonaria in VS. Growth layering and the thick pillars are clearly visible (red arrows); the thin cyst plates are faintly visible, see Figs. 7 \& 8; b Enlargement of the yellow box in Fig. 4 showing the structure of $L$. carbonaria in TS, where the pillars are sectioned transversely (red arrows). At the bottom of the picture, the pillars are sectioned obliquely. $\mathbf{a}$ is BGS image number P820968 of sample UKBGS.GSM51517; $\mathbf{b}$ is BGS image number P820974 of sample UKBGS.GSM51516. Both images are reproduced with the permission of the British Geological Survey@UKRI. All rights Reserved

\subsection{Labechia carbonaria taxonomic affinity}

Detailed discussion of the structure of $L$. carbonaria is required to establish its affinity; also comparisons between L. carbonaria (Early Carboniferous) and L. conferta are highly instructive in a debate about the affinity of $L$. carbonaria. Note that $L$. conferta is regarded by Webby $(2015$, p. 720$)$ as a species group and ranges from Darriwilian (Middle Ordovician) to Famennian (Upper Devonian); the sample illustrated in Fig. 10 is Wenlock (Silurian). The two taxa are clearly very similar in general arrangements of their architecture and microstructures, evidence that they belong within the same genus of stromatoporoids.

The interpretation by Sokolov (1955) of a chaetetid classification for $L$. carbonaria is addressed by comparison with Carboniferous chaetetids. Figure 12 shows representative thin section views of a Carboniferous chaetetid, where in both VS and TS the structure is completely different from $L$. carbonaria. The polygonal calicles possessing tabulae, in chaetetids, has no equivalent in $L$. carbonaria, so we exclude a chaetetid interpretation.

Further comparison between $L$. carbonaria and rugose corals is also important. Rugosan microstructure is typified by trabeculae (Hill 1981), which are rods composed of chevron-arranged crystal fibres, of varied and complex structure (see also Kato 1963). As illustrated in Figs. 8 and 11, the microstructure of both Labechia taxa contains chevron-like structures that resemble trabeculae in corals, a point noted by Stearn (2015c, p. 524), who also illustrated transverse fibrous structures in stromatoporoid skeletons (Stearn 2015c, Fig. 336). Stromatoporoids become recrystallised so that diagenetic cements cut across the skeletal elements (e.g. Figures 9 and 11), an indication of an unstable original mineralogy (presumably either aragonite or high-Mg calcite), in contrast to the well-known stability of calcite structure in Rugosa. 

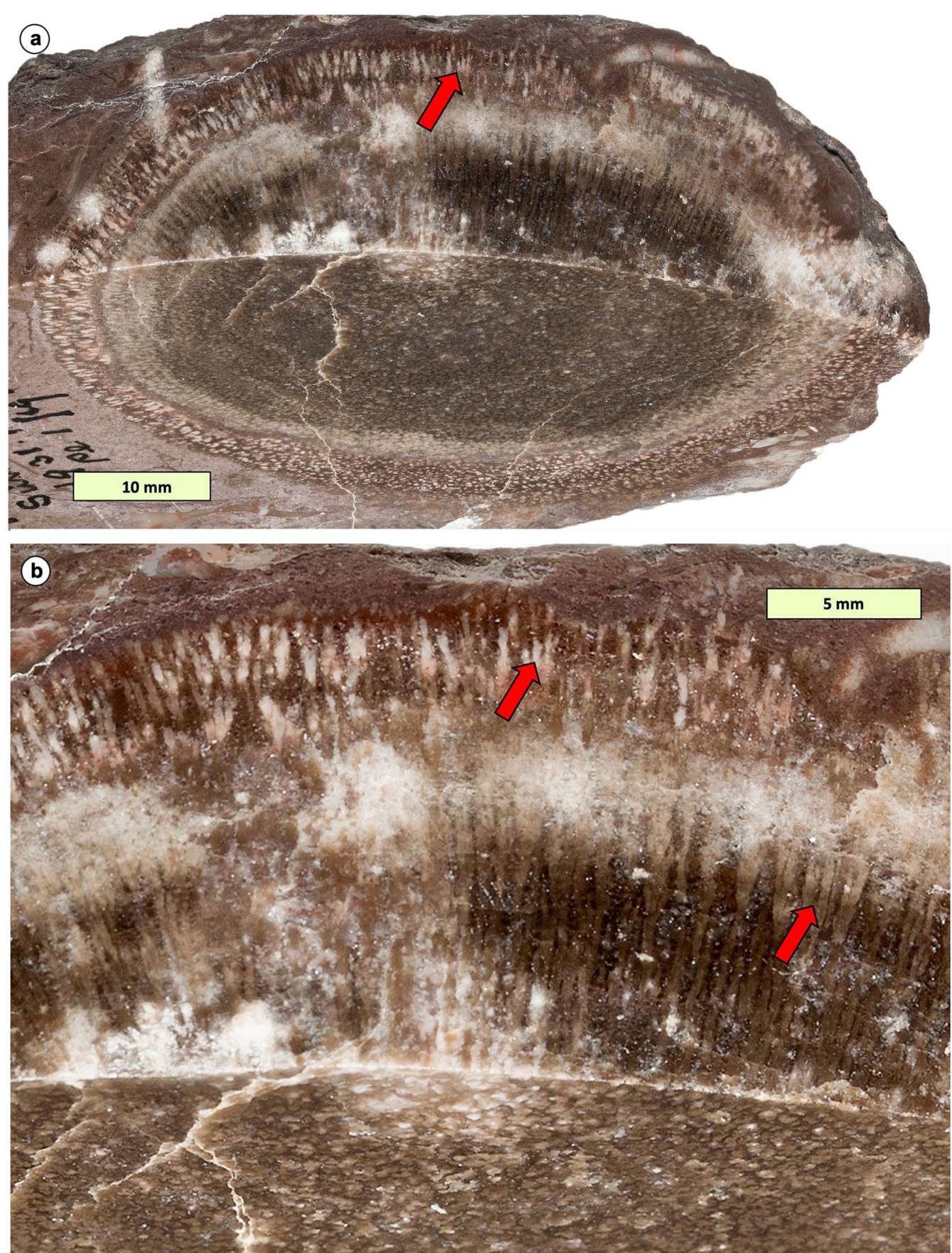

Fig. 6 The sample illustrated in Fig. 4 had been previously cut and polished to reveal the three-dimensional structure of L. carbonaria, so that both TS and VS views are visible in one specimen. The sample is orientated the correct way-up, showing the apparent upward-branching nature of the pillars (red arrows). a Overall view of the sample; $\mathbf{b}$ Enlargement of the central part showing the pillars as lighter-coloured dots in TS and as thick lines in VS. BGS image number P995345 of sample UKBGS.GSM51516, reproduced with the permission of the British Geological Survey@UKRI. All rights Reserved

However, although trabeculae in rugose corals are generally well-preserved (e.g. Schröder and Soto 2003 for Devonian Rugosa; Fedorowski 2008; Coen-Aubert et al. 2013; Fedorowski et al. 2019 for Lower Carboniferous Rugosa), they can suffer diagenetic alteration that degrades the structure, although remnant trabecular structure is normally still visible. A very good example was provided for Permian Rugosa by Fedorowski and Bamber (2001, Pls 5 \& 6), where altered trabeculae retained their laminated structure. Observations of 


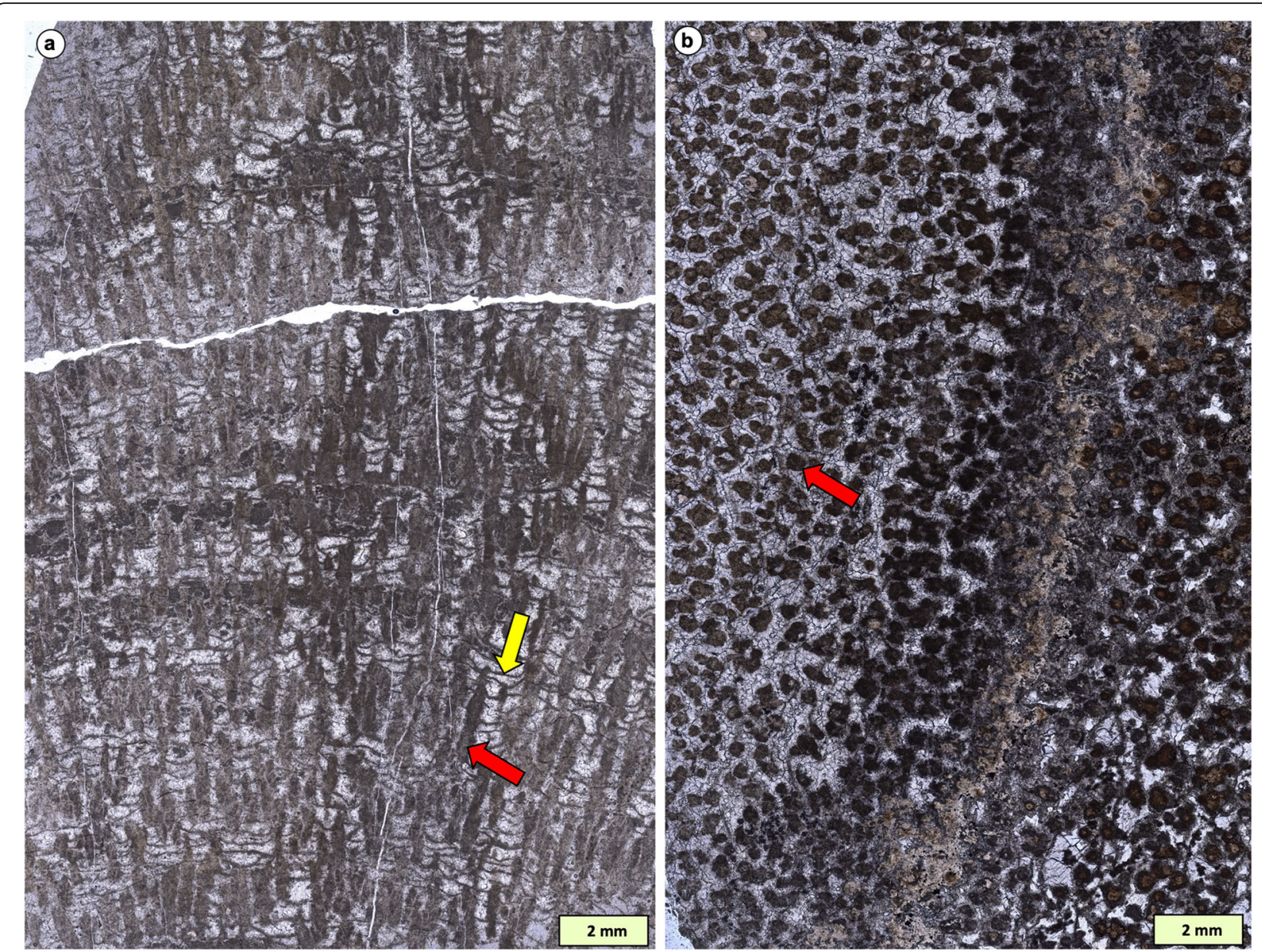

Fig. 7 Skeletal architecture of Labechia carbonaria in thin section. a Vertical section showing prominent thick long pillars (red arrow) and thin connecting cyst plates (yellow arrow) that are either flat, or slightly upwardly or downwardly curved. This thin section was cut slightly oblique to the vertical growth of the fossil, so the pillars are not cut perfectly vertically, but this does not prevent its easy recognition as a Labechia-form structure. Pillars are variably spaced in the structure but do not form alignments. Cyst plates are different lengths to achieve linkage between pillars. Growth layers are also visible as darker curved lines across the picture; $\mathbf{b}$ Transverse section showing pillars that have variable rounded shape in TS, some are amalgamated. The broad dense area, centre, is a slightly oblique TS through a growth layer, along which there is some recrystallisation of the structure. To the right of centre, pillar density is greater than the left. The left one-third of the picture is either stratigraphically above or below the right one-third and may be an indication of change in growth rate of the structure. $\mathbf{a}$ is sample number NHMUK PI S 10490\$1; b is sample number NHMUK PI S 10491\$1; both thin sections are labelled as having been made from the syntype and we presume these were cut from samples held by the BGS, possibly the paratype and holotype respectively, but this is unconfirmed. Photos taken by the authors

rugose corals in Silurian material held by SK shows that some of them have altered trabeculae. In some cases, rugose trabeculae can be completely recrystallised, but the range of preservation in rugosans contrasts stromatoporoids, which are always recrystallised. Thus, it is not a simple matter to use the difference of preservation of microstructure as a distinguishing criterion between rugose corals and a potential stromatoporoid affinity of $L$. carbonaria. Nevertheless, the similarity of chevron microstructure in L. conferta (Fig. 10), a confirmed stromatoporoid sponge (Webby 2015), and the same in $L$. carbonaria, together with the pillar and cyst plate architecture, means there is not a barrier to a stromatoporoid interpretation of L. carbonaria.

Although there is potential confusion between broken pieces of rugose coral and a possible stromatoporoid structure, put forward by Stearn (2015a) as a problem for a stromatoporoid affinity of $L$. carbonaria, another aspect of rugose corals must be considered. In order for the $L$. carbonaria structure to be a rugose coral, it would be necessary for the pillars to represent free trabeculae (not forming septa). However, although free trabeculae occur in rugose corals, they are not known in rocks younger than Middle Devonian. Perusal of images in the 

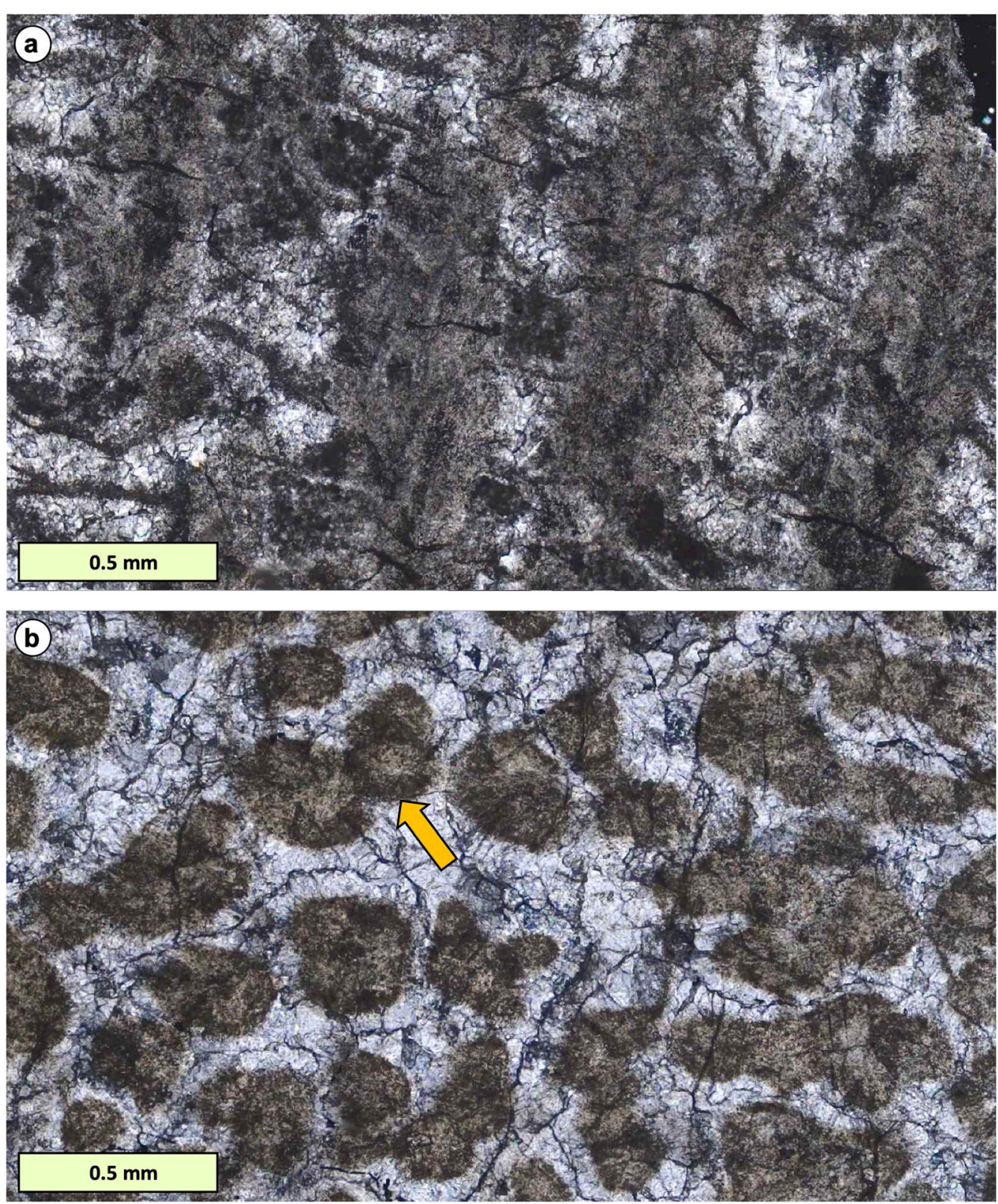

Fig. 8 Enlargement from Fig. 7 showing details of structure of Labechia carbonaria in thin section. Both photographs are in cross-polarized light, in which the structure is easier to see in these rather thick sections; therefore dark areas of the pictures are portions of calcite crystals in extinction. Narrow slightly irregular short dark lines are fractures in the structure, presumably from the grinding process that has partly broken the rock slices in these particular samples. a Vertical section of pillars and cyst plates and interstitial cement. All four pillars illustrated here show the micritic structure (compact microstructure) of the skeleton, that has a faint downward-pointing chevron-form pattern of indistinct laminations merging along the centre line. Note that the structure of L. carbonaria lacks the curved cone-in-cone type of architecture illustrated in Fig. 10 for Labechia conferta; $\mathbf{b}$ Transverse section showing pillars and indistinct cyst plates with interstitial cement. Pillars in TS reflect the chevron-form pattern (shown in a) by density variation in the pillars. The arrow shows one pillar with a lighter centre and darker rim, presumably a concentric feature of the chevron pattern. $\mathbf{a}$ is Sample number NHMUK PI S 10490\$1; $\mathbf{b}$ is sample number NHMUK PI S 10491\$1. Photos taken by the authors

1981 Coelenterate Treatise (Hill 1981) shows that Carboniferous rugose corals have septa and not free trabeculae. Examination of all hand specimens and thin sections of the extensive collection of Carboniferous rugosa in the Natural History Museum as part of this study did not find any samples that lacked fully-formed septa (see Fig. 13).

Drawing together the attributes of L. carbonaria: a) it is composed of pillars and cyst plates with a microstructure very similar to $L$. conferta; b) it lacks septa (proven 

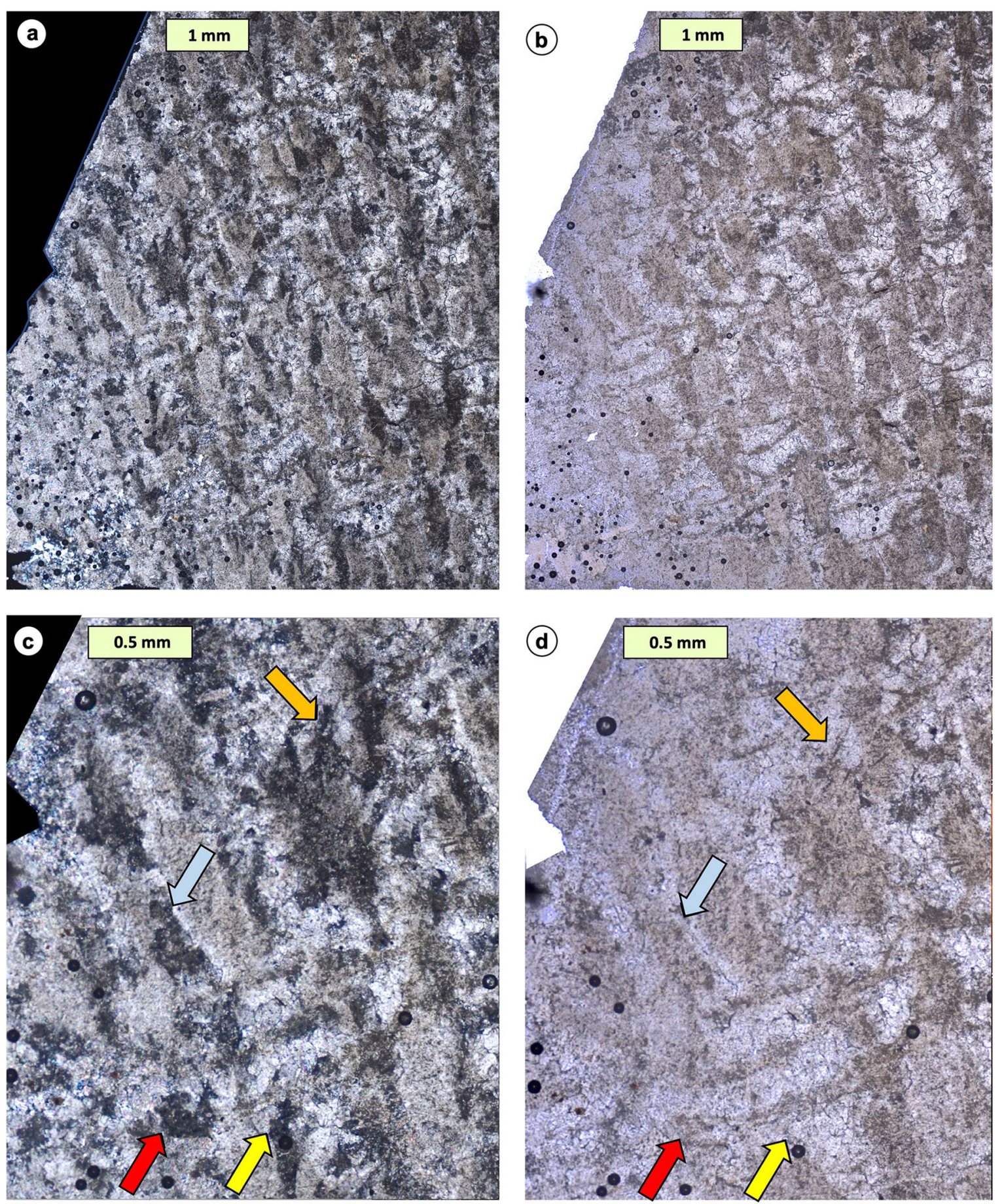

Fig. 9 Skeletal architecture of Labechia carbonaria in vertical thin section, selecting the margin of the section where the hand-ground thin section is thinner than the rest of the section. $\mathbf{a} \& \mathbf{b}$ Paired photographs in $\mathrm{xpl}(\mathbf{a})$ and $\mathrm{ppl}(\mathbf{b})$ revealing that the skeletal structure in $\mathbf{b}$ has been overprinted by sparitic calcite that crosses into space between skeletal elements and demonstrates that the skeletal structure is recrystallised. c \& d Paired photographs in $\mathrm{xpl}(\mathbf{c})$ and $\mathrm{ppl}$ (d) showing enlargement of the centre-left part of $\mathbf{a} \& \mathbf{b}$ The overprinting by recrystallisation of sparite, crossing through the skeleton into intra-skeletal spaces is highlighted in four places by paired coloured arrows; note that these four are only examples, in fact the entire structure is recrystallised, which a ubiquitous feature of Palaeozoic stromatoporoids, see Discussion. Sample number NHMUK PI S 10490\$1; Photos taken by the authors 

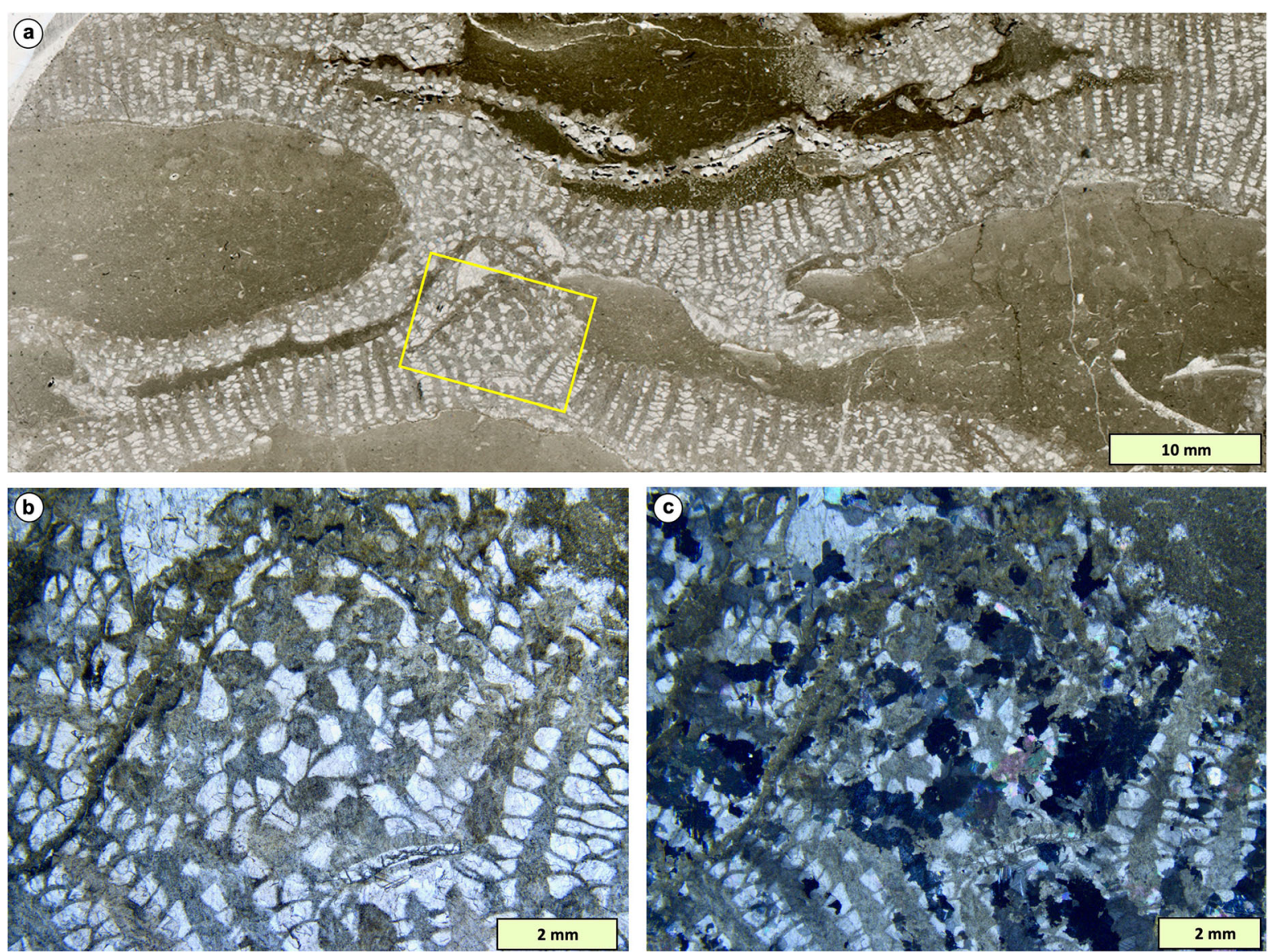

Fig. 10 Skeletal architecture of Labechia conferta (Lonsdale) in thin section, from the Much Wenlock Limestone Formation, middle Silurian of Wren's Nest, Dudley, England, to show comparison with Labechia carbonaria in Figs. 7, 8, 9. a Whole thin section in vertical section showing the arrangement of pillars and cyst plates in a laminar form of L. conferta. $\mathbf{b}$ \& $\mathbf{c}$ Enlargements of the yellow box in $\mathbf{a}$, showing both VS and TS sections within the same area of thin section, due to curvature of the stromatoporoid. Thus the centre of the view is TS and other areas are VS. $\mathbf{b}$ is in plane-polarised light and $\mathbf{c}$ is in cross-polarised light. Sample from Sedgwick Museum, Cambridge, UK, number X.50347.187

by observation in VS and TS) that are features of Carboniferous rugose corals (Fig. 13). L. carbonaria does not resemble a chaetetid, based on comparisons between Figs. 3, 4, 5, 6, 7, 8 and 9 (L. carbonaria) and Fig. 12 (chaetetid) and illustrations of chaetetids in West (2011). On the basis of these points we conclude that Labechia carbonaria is a stromatoporoid.

\subsection{Implications for the palaeogeography and geological history of stromatoporoids}

Stearn (2015a) discussed the issue of extinction of Palaeozoic stromatoporoids at the end of the Devonian Period, including summary of the various ideas regarding $L$. carbonaria. Smith (1932) viewed $L$. carbonaria as a species of Labechia and thus a stromatoporoid. Mistiaen (1984, 1994) presented an argument that the Palaeozoic stromatoporoids did not become extinct at the end of the Devonian Period. Instead, in this theory stromatoporoids lost their ability to calcify, following the proposed changes in ocean saturation from calciteprecipitating seas to aragonite-precipitating seas in the Late Devonian to Early Carboniferous, relating to tectonic cycles (Sandberg 1983). On this basis, stromatoporoids thus began calcifying again in the Mesozoic when calciteprecipitating seas were re-established. The final change back to aragonite-precipitating seas around the Cretaceous-Palaeogene boundary may thus explain the lack of stromatoporoids in the Cenozoic (noting that a few taxa of stromatoporoid-type calcified sponges are known as living organisms today). We note that since Sandberg's (1983) and Mistiaen's (1984, 1994) work, ideas on the aragonite-calcite seas debate have developed. Balthasar and Cusack (2015) showed the exact timing of changeover from calcite seas to aragonite seas around the time of the Early Carboniferous is subject to interpretation, which means that there is imprecision in the correlation between stromatoporoid extinction and the change from calcite to aragonite seas. We further wish to note that there is no 

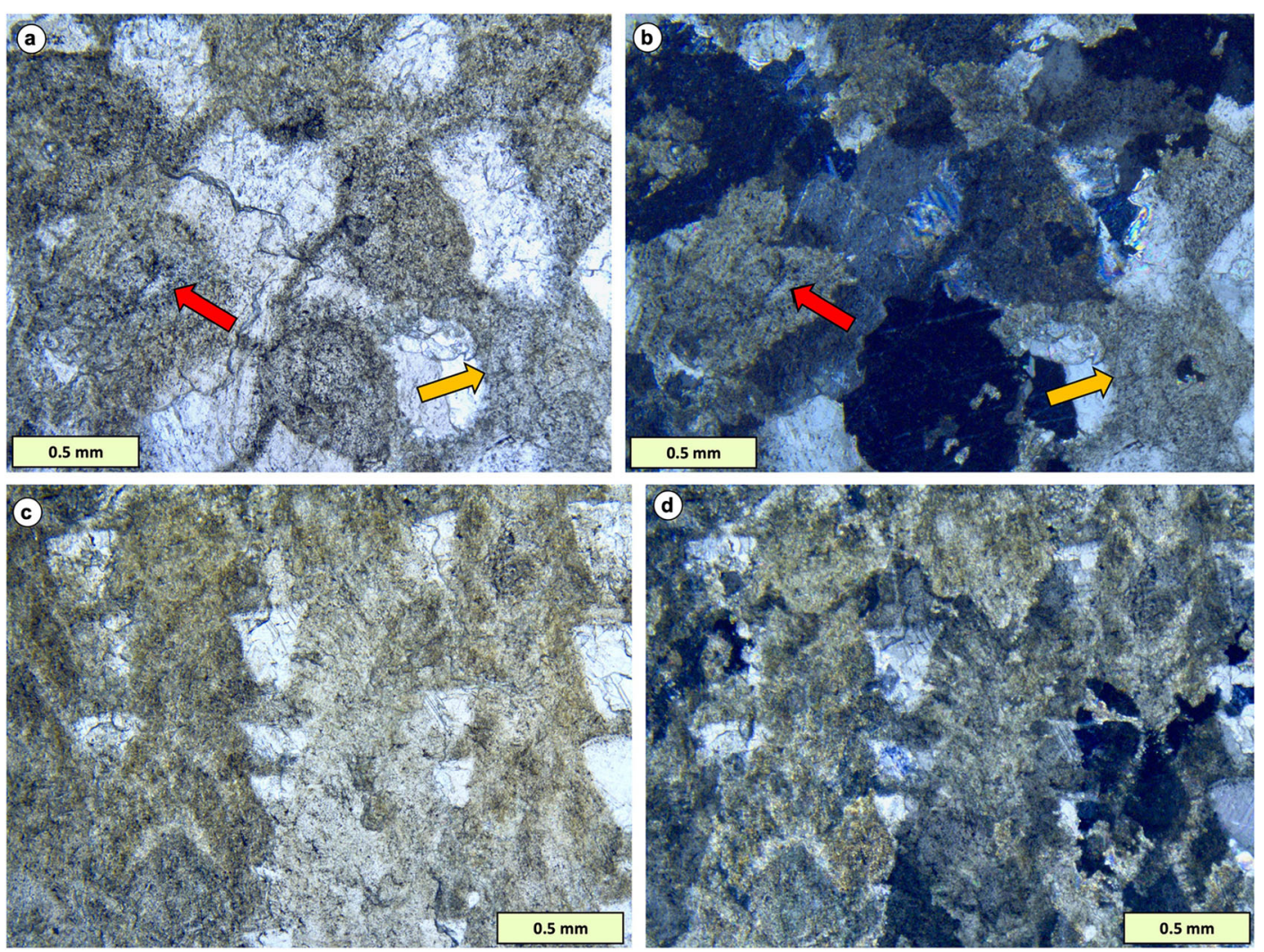

Fig. 11 Details of skeletal architecture of Labechia conferta (Lonsdale) in thin section, from the Much Wenlock Limestone Formation, middle Silurian of Wren's Nest, Dudley, England, to show comparison with Labechia carbonaria in Figs. 7, 8, 9; enlargements from the sample illustrated in Fig. 10. a \& b Transverse sections showing pillars and cyst plates in $\mathrm{ppl}(\mathbf{a})$ and $\mathrm{xpl}(\mathbf{b})$. The structure is composed of micritic skeletal material (compact microstructure). Red and orange arrows show the same pillars in each view, revealing a faint concentric structure, similar to L. carbonaria in Fig. 8b. c \& d Vertical section showing three pillars, and half a pillar on the left side in $\mathrm{ppl}(\mathbf{c})$ and $\mathrm{xpl}(\mathbf{d})$. Short cyst plates connect the pillars and partly merge with them. The compact microstructure also includes a curved cone-in-cone fabric that was not observed in L. carbonaria, plus a fibrous architecture of upwardly diverging indistinct crystals, similar to $L$. carbonaria in Fig. 8a. Xpl views show partial overprinting of the structure by diagenesis, particularly well-shown in b (top-left and top-right pillars are partly extinct in multiple calcite crystals, and bottom centre pillar fully extinct in one calcite crystal) and in d (right hand pillar). In $\mathbf{b}$ and $\mathbf{d}$, the xpl view accentuates the cone-in-cone and chevron architecture. Sample from Sedgwick Museum, Cambridge, UK, number X.50347.187.

proof that stromatoporoid calcification processes were really influenced by the $\mathrm{Ca}: \mathrm{Mg}$ ratio of the oceans, although the arguments are well-known following the seminal work of Stanley and Hardie (1998).

Although Mistiaen's (1984, 1994) proposals are in line with popular thinking about the Phanerozoic changes in the oceans, notwithstanding the imprecision of timing noted above, it does not resolve the issue with a related group of hypercalcified sponges, the chaetetids. Chaetetids range from Ordovician to Eocene (West and Kershaw 1991) and are not recorded after the Eocene until their presence in living assemblages in genus Acanthochaetetes. The reasons for their paucity in the Palaeogene and Neogene have not been discovered. However, chaetetids are abundant in the Carboniferous System, in both Mississippian and Pennsylvanian strata (West 2011). Given the recognition that hypercalcified sponges are polyphyletic (e.g. Vacelet 1985), and taxonomic groupings of sponges cut across the division of the mineralised skeleton into calcified types of stromatoporoids and chaetetids (often referred to as "grades" of organisation), then a general loss of ability to calcify in stromatoporoids in response to the calcite/aragonite seas changes, would be expected to extend to chaetetids. Because that is not true, an alternative proposal takes account of the haphazard occurrence of calcification, known in modern sponges. Most sponges are noncalcifying (e.g. Wulff 2016) and even within some modern genera some species calcify while others do not (e.g. the genus Merlia, see West 2011). Thus it may be that calcifying taxa of stromatoporoid-form sponges almost completely died out at the end of the Devonian whereas non-calcifying taxa did not. Loss of hypercalcifying taxa (which includes stromatoporoids) in mass extinctions has been mooted (e.g. Knoll and Fischer 2011), although that was a proposed response to ocean acidification, at for example, the end-Permian event. Loss of calcification in stromatoporoids at the end of the Devonian, followed 

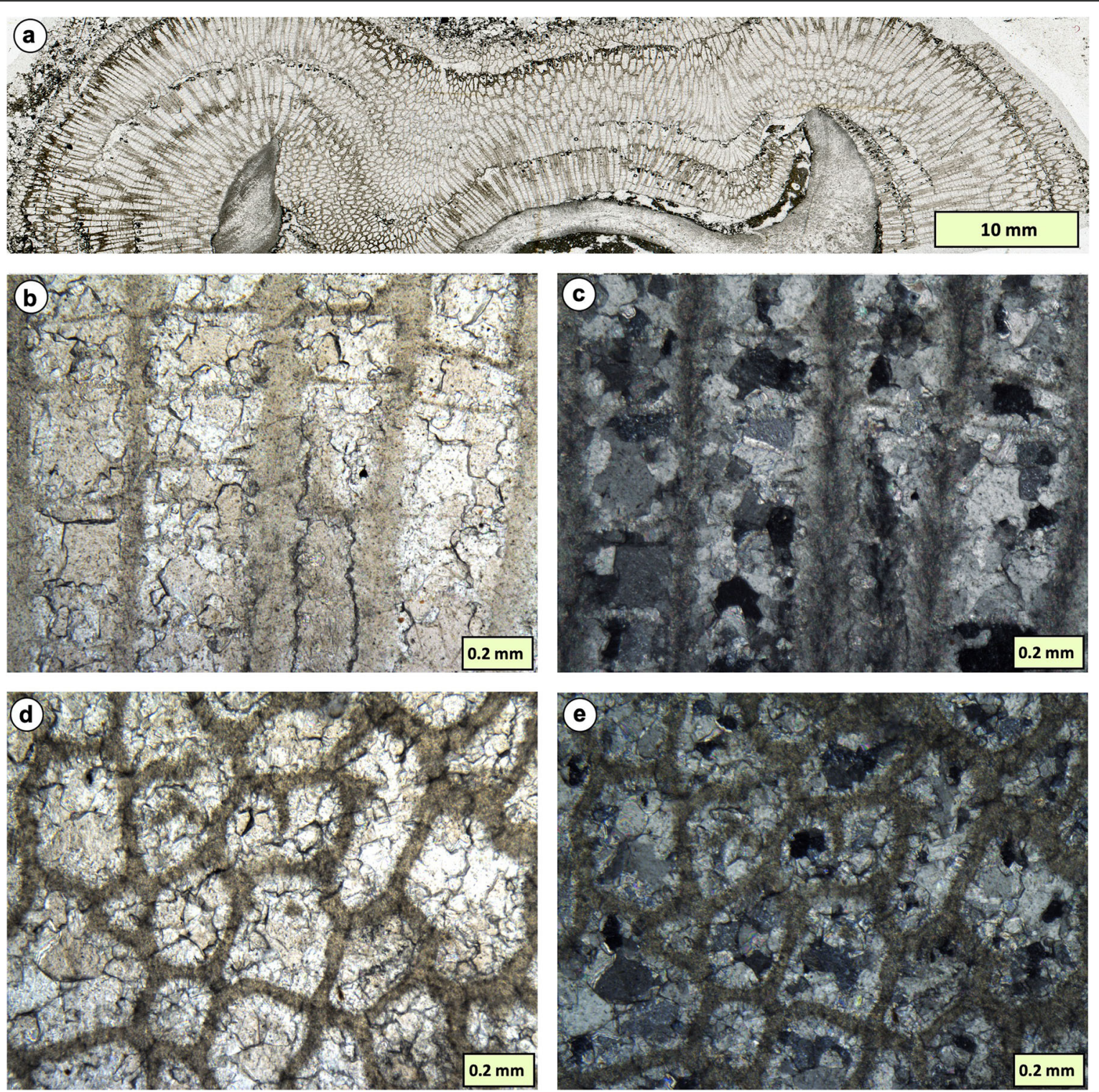

Fig. 12 Thin section views of a representative chaetetid from the Early Carboniferous System showing the structure of vertically-arranged calicles in vertical section, that are polygonal in transverse section. b \& c Plane-polarised (b) and cross-polarised (c) light enlargements of a vertical section showing thick calicle walls with oblique fibrous structure, and horizontal tabulae. $\mathbf{d} \& \mathbf{e}$ transverse section showing polygonal calicles, which do not occur in Labechia. c \& e show the chaetetid wall structure is barely affected by recrystallisation, in contrast to the stromatoporoid illustrated in Fig. 9. Sample from the Eglwyseg Escarpment, North Wales, donated by lan Somerville

by expansion of chaetetids in the Early Carboniferous, would be difficult to attribute to a general loss of hypercalcifying taxa. Nevertheless, the fact that sponges are abundant through geological time (Muir et al. 2017, Fig. 2.1 ) is a clear indicator of sponge survival through mass extinctions. The difference between extinction of calcifying stromatoporoid-form sponges and expansion of calcifying chaetetid-form sponges may be at the low-levels of taxonomy, so that individual sponge species that happened to have stromatoporoid-type skeletons died whereas species with chaetetid-type skeletons did not.
Sponges show variety of groups through the Carboniferous, although Muir et al. (2017) showed their diversity was lower in the Carboniferous than at other times in the Palaeozoic Era. Although the chaetetid calcified sponges expanded, particularly in early to middle Carboniferous time, other sponge groups are less represented. Sponges occur in some Early Carboniferous build-ups (e.g. Rigby and Mundy 2000) in which hypercalcified sponges are missing. It remains a curious fact that stromatoporoids did not occupy these facies, despite the evidence presented in this study that they still 


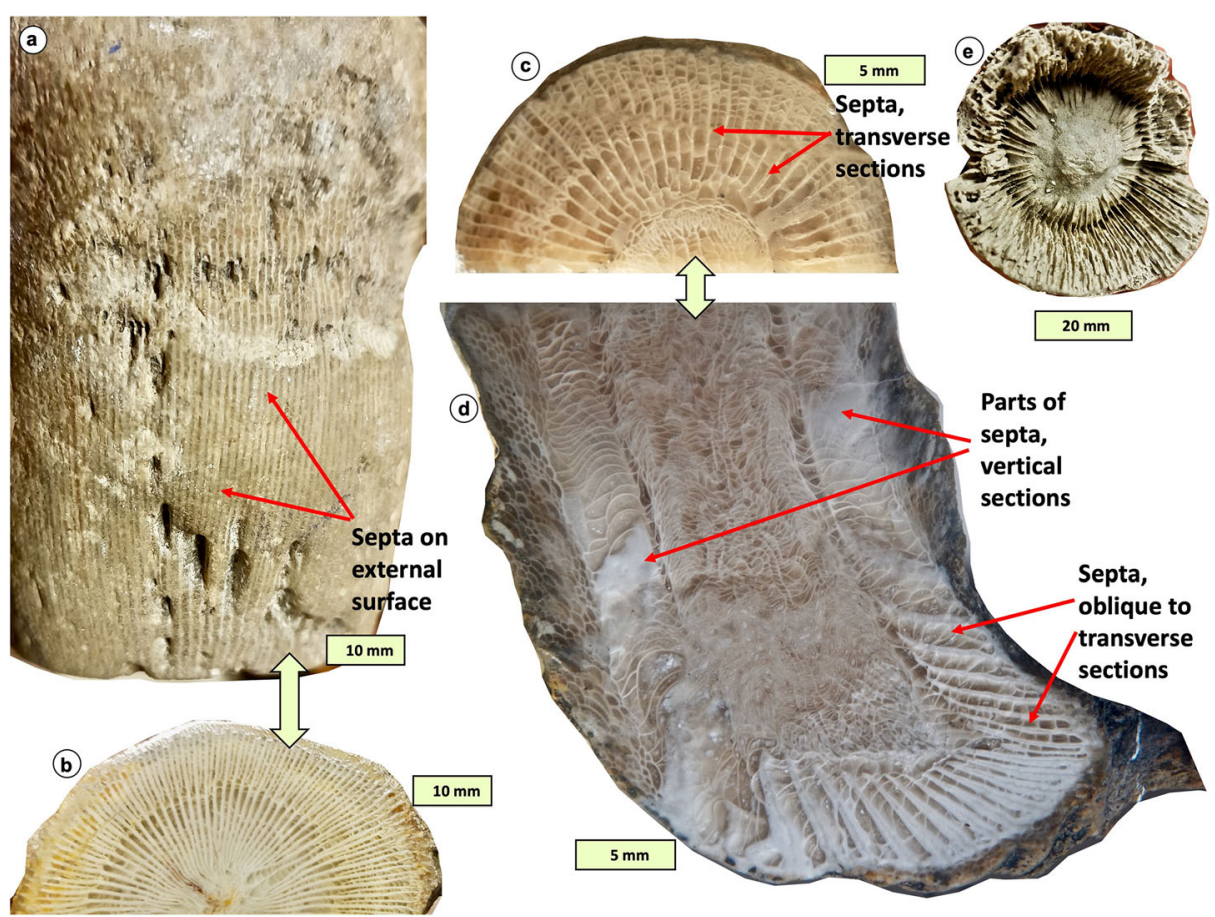

Fig. 13 Examples of Lower Carboniferous rugose corals from England, showing rugose coral septa, to emphasise the difference between these and the structure of Labechia carbonaria. $\mathbf{a}$ \& $\mathbf{b}$ Cyathophyllum NHMUK PI R16758, Bed of Hart, Northumberland. $\mathbf{a}$ External surface showing septa in vertical cross section; $\mathbf{b}$ Transverse section (TS) showing radially arranged septa. Note that Cyathophyllum is generally considered a Devonian taxon, so use of that name may be incorrect here, but this is a Carboniferous specimen; c \& $\mathbf{d}$ Unidentified and uncatalogued rugosan. c TS showing radial septa. $\mathbf{d}$ Vertical section (VS) in the upper part, where vertical sections of septa partly intersect the plane of section (labelled); in the lower part, oblique to transverse sections are revealed due to curvature of the coral; e Top view of a rugose calyx showing radial arrangement of septa. Auloclisia, NHMUK PI R25872, Lower D1 Biozone (Asbian, just above the level of the Seventh Limestone), Isle of Man. Photos taken by the authors

existed in Early Carboniferous time. Thus, selective almost-complete extinction of sponge taxa that formed stromatoporoid-type skeletons is a reasonable explanation for their paucity after the end-Devonian event, compared to expansion of chaetetid-form taxa.

More information is available from Devonian stromatoporoids. Labechia-form stromatoporoids show an indication of ability to survive extinction, in their expansion after the Frasnian-Famennian (F/F) extinction event (Stearn 2015b, Fig. 361). Stearn (2015a, p. 605) provided details of changes in stromatoporoid taxa during the Famennian and stressed the remarkable expansion of Labechiid-type stromatoporoids during this last phase of Palaeozoic stromatoporoid development prior to the Hangenberg Crisis. Stearn (2015a, p. 605) in particular drew attention to the rarity of Labechiid-type stromatoporoids in the Devonian System against the backdrop that stromatoporoids in general had their greatest expansion in the Eifelian and Givetian Series. Discussion by Stock et al. (2015) summarised palaeobiogeographic changes of Palaeozoic stromatoporoids from Middle Ordovician to Late Devonian time and showed that Famennian stromatoporoids are present in most lower latitude locations globally up to the end of their range. However, Stock et al. (2015, p. 688) noted that Labechiid-type stromatoporoids do not occur throughout all of the Devonian System in the East Americas Realm (EAR, consisting of SE North America \& NW South America, see Fig. 1a), and there are no Famennian stromatoporoids at all in the EAR.

The presence of $L$. carbonaria in Early Carboniferous rocks, $c a 22$ million years after the Hangenberg Crisis is evidence that hypercalcified stromatoporoid sponges did survive the extinction, presumably in very low numbers and, given their expansion after the F/F extinction, Labechia-form taxa may be the obvious ones to have survived into the Carboniferous. Nevertheless, despite this argument, search for post-Devonian stromatoporoids has revealed very little. If the palaeontological community accepts the conclusion of this study that $L$. carbonaria is a Labechia-form stromatoporoid then it is only the second robust example of stromatoporoid type known from the Carboniferous System, the other being a single specimen of the Pennsylvanian of Kansas, Newellia mira (Newell 1935; Wood et al. 1989). Nevertheless, there are two other taxa that have been considered as potential stromatoporoid-type calcifiers. 


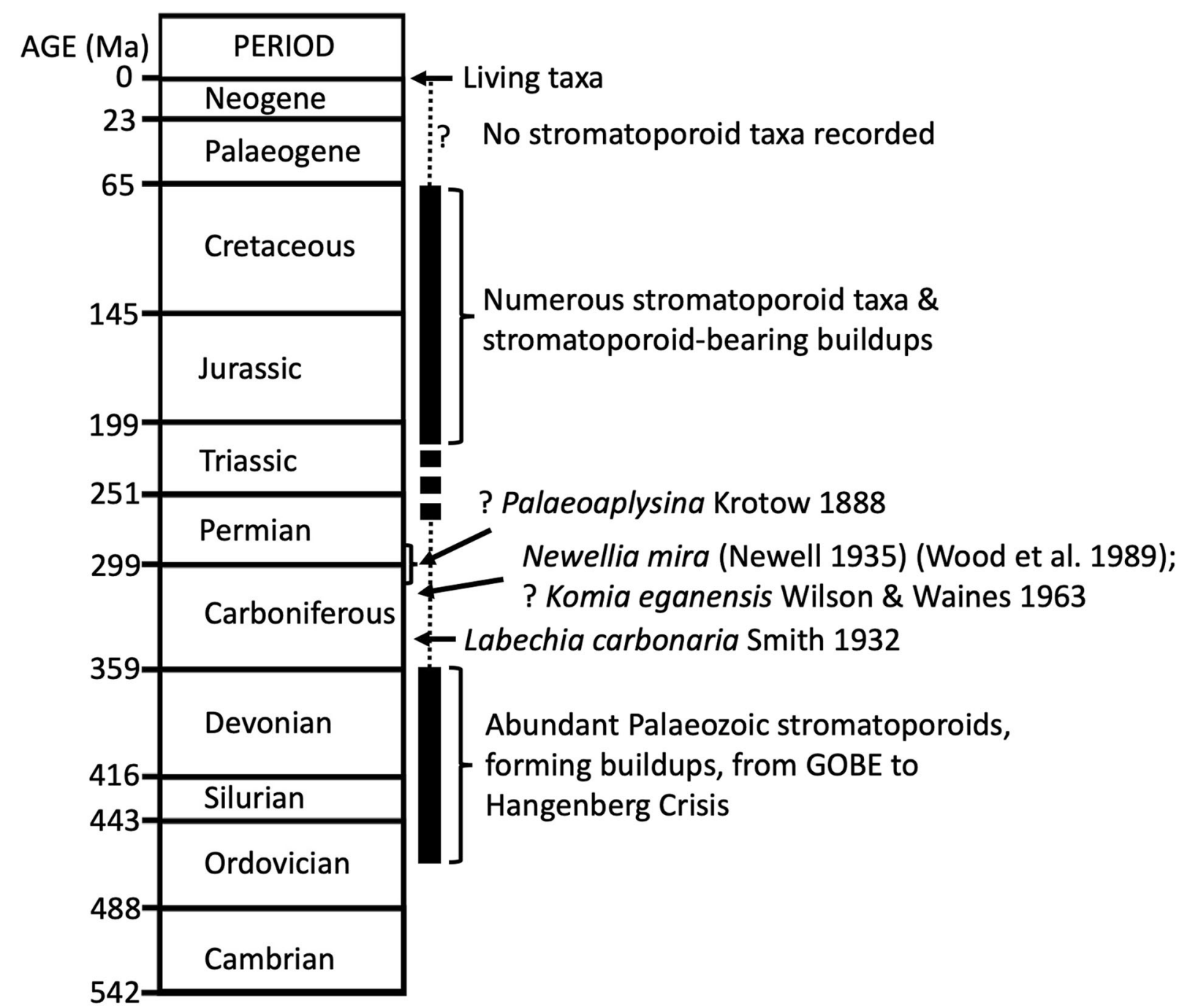

Fig. 14 Phanerozoic geological succession showing a sketch of the history of stromatoporoid-form calcified sponges. Palaeozoic stromatoporoids range from the time of the Great Ordovician Biodiversification Event (GOBE) in the Middle Ordovician and are traditionally recognised to have become extinct at the end-Devonian Hangenberg Crisis. In the Carboniferous, Labechia carbonaria is Lower Carboniferous, and in the Upper Carboniferous only one sample, Newellia mira (Newell 1935) is confirmed. Two other fossils (Komia in the Upper Carboniferous and Palaeoaplysina in the Upper Carboniferous to Lower Permian) that have been attributed to stromatoporoids by other authors are annotated with question marks. See text for discussion

Wilson et al. (1963) proposed that the taxon Komia Korde from the middle Pennsylvanian of eastern Nevada is a stromatoporoid. Ponomarenko et al. (2014) reinterpreted the Upper Carboniferous to Lower Permian taxon Palaeoaplysina (Krotow 1888) (sampled from the Ural Mountains in Russia) as a hydrozoan, but noted earlier hypotheses that this fossil may be a stromatoporoid.

Both Komia and Palaeoaplysina are included in the list of Upper Palaeozoic-Mesozoic stromatoporoid-like taxa by Stearn and Stock (2015); thus it remains unclear as to the affinity of these taxa.

Overall, therefore, an optimistic view of post-Devonian Palaeozoic stromatoporoids is that they diversified into other forms, some of which are difficult to classify. A pessimistic view is that stromatoporoids almost disappeared at the end of the Devonian and continued in very low numbers until their return to greater abundance in the Jurassic. However, the chance of three boreholes and one outcrop in England yielding samples containing L. carbonaria in the same limestone unit is remarkable if they are rare. The existing $L$. carbonaria samples raise the question about whether there are more in the deposits, that might be revealed in future collecting. The report by Stock et al. (2015, p. 688) that no stromatoporoids occur in the Famennian in the East Americas Realm (EAR) may provide focus for potential search of further Carboniferous stromatoporoids elsewhere. It is thus perhaps not surprising that Labechia 
carbonaria was found in a location to the east of the EAR (where the British Isles was positioned, Fig. 1a). Newellia was found in Kansas and Komia from Nevada, neither of which are in the EAR areas (see Blodgett et al. 1990, their Fig. 4 palaeogeographic map of realms). Furthermore Palaeoaplysina is from Russia, distant from the EAR. Of course, there are many millions of years of time between Famennian and Viséan occurrences of stromatoporoids, during which any surviving lineages may have moved geographic position, but this discussion may stimulate further research for stromatoporoid-type sponges. In perspective, Carboniferous strata show: a) stromatoporoid-type calcified sponges are known in England and Pennsylvania, and possibly in Nevada and Ural Mountains of Russia; and b) chaetetid-type calcified sponges are widespread and known in North America, Europe, Russia, Australia, Afghanistan, China and Japan (West 2011, p. 181).

\section{Conclusions}

1) The structure of Labechia carbonaria is composed of pillars and cyst plates, consistent with identification as a stromatoporoid of the Labechia form. Previous interpretations that $L$. carbonaria was a chaetetid or rugose coral are shown to be incorrect and L. carbonaria is confirmed as a stromatoporoid, in the Mississipian Viséan Series, approximately 22 million years after the endDevonian extinction of stromatoporoids.

2) Confirmation of a second occurrence in Carboniferous strata of a stromatoporoid-type sponge (the first is upper Pennsylvanian Newellia mira (Newell 1935)) adds to knowledge of stromatoporoid geological history; $L$ carbonaria is older than N. mira. Two other taxa in the Carboniferous, Komia and Palaeoaplysina, have been variously interpreted, including a stromatoporoid-type sponge affinity; if they are stromatoporoids, then the total presence of stromatoporoid-type sponges in the Carboniferous may be higher than previously recognised.

3) Most sponge taxa do not calcify, and within certain modern genera there are species that calcify and others that do not. The previous proposal that stromatoporoids lost their ability to calcify at the end of the Devonian is considered here unlikely. Instead we propose that almost all calcified stromatoporoid-form taxa died out at the Hangenberg Crisis, leaving rare survivors. A reasonable interpretation is that uncalcified taxa did not die out, providing the rootstock of sponges that resumed calcification in the Mesozoic to leave stromatoporoid fossils once more.
4) We concur with earlier studies that offer the view that Palaeozoic and Mesozoic stromatoporoids are not so different and, notwithstanding the gaps in the Carboniferous-Triassic record, stromatoporoidtype sponges had a presence in the rock record between Early Ordovician and latest Cretaceous time. The lack of stromatoporoid-type sponges in the Cenozoic, until their appearance in modern reefs, is not yet explained.

\section{Abbreviations}

BGS: British Geological Survey; EAR: East Americas Realm (palaeogeographic area); ESE: East southeast; NE: Northeast; NHM: Natural History Museum; SW: Southwest; TS: Transverse section of a stromatoporoid, chaetetid and coral (other publications sometimes call this tangential section); VS: Vertical section of a stromatoporoid, chaetetid and coral (other publications sometimes call this longitudinal section)

\section{Acknowledgments}

We are very grateful to the British Geological Survey for access to samples and permission to reproduce their illustrations of Labechia carbonaria hand specimens, and particularly thank Michael Howe, Paul Shepherd, Simon Harris and Louise Neep for their assistance. In the Natural History Museum, we are grateful to Richard Turney and Jill Darrell for help with photography and accessing Carboniferous coral specimens respectively. We thank Julien Denayer (Liège) for discussion of rugose corals at an early stage of the work. We are grateful to Markus Aretz for helpful comments and advice on an earlier version of this script and thank anonymous reviewers for their comments. Ian Somerville (Dublin) is thanked for donation of the chaetetid sample illustrated in Fig. 12.

Authors' contributions

Interpretations, analysis, discussion and conclusions were undertaken by both authors, who have read and approved the final manuscript.

Funding

No specific funding was available for this work.

\section{Availability of data and materials}

All data presented in this study are included in the script and figures. The samples are held by the British Geological Survey and Natural History Museum, both in the UK.

\section{Competing interests}

The authors declare that they have no competing interests.

Received: 12 May 2020 Accepted: 2 October 2020

Published online: 02 November 2020

\section{References}

Balthasar, U., and M. Cusack. 2015. Aragonite-calcite seas-quantifying the gray area. Geology 43: 99-102. https://doi.org/10.1130/G36293.1.

Blodgett, R.B., D.M. Rohr, and A.J. Boucot. 1990. Early and middle Devonian gastropod biogeography. In Palaeozoic Palaeogeography and Biogeography, ed. W.S. McKerrow and C.R. Scotese, 277-284. London: Geological Society Memoir No. 12.

Coen-Aubert, M., R. Gourvennec, O. Monod, Y. Plusquellec, and F. Tourneur. 2013. Frasnian rugose and tabulate corals from the eastern Taurus (Kozan region, Turkey). Geodinamica Acta 26: 68-93. https://doi.org/10. 1080/09853111.2013.858944.

Dean, M.T., M.A.E. Browne, C.N. Waters, and J.H. Powell. 2011. A lithostratigraphical framework for the Carboniferous successions of northern Great Britain (onshore). In British Geological Survey Research Report, RR/10/07, 174pp. London: HMSO.

Fedorowski, J. 2008. Early Carboniferous Chinese and Australian "Siphonodendron" (Anthozoa, Rugosa): Ecological and geographical influence on taxonomy. Geologos 14: 3-17. 
Fedorowski, J., and E.W. Bamber. 2001. Guadalupian (middle Permian) solitary rugose corals from the Degerböls and Trold Fjord formations, Ellesmere and Melville Islands, Canadian Arctic archipelago. Acta Geologica Polonica 51: 31-79.

Fedorowski, J., E.W. Bamber, and B.C. Richards. 2019. Bashkirian rugose corals from the Carboniferous Mattson formation in the Liard Basin, Northwest Canada-Stratigraphic and paleobiogeographic implications. Acta Palaeontologica Polonica 64: 851-870.

Garwood, E.J. 1913. The lower Carboniferous succession in the north-west of England. Quarterly Journal of the Geological Society of London 68: 449-572.

Hill, D. 1981. Rugosa and Tabulata. In Treatise on Invertebrate Paleontology. Part F, Coelenterata, Supplement 1, vol. 2, ed. C. Teichert, 379-762. Boulder, Colorado, \& Lawrence, Kansas: The Geological Society of America \& the University of Kansas.

Kato, M. 1963. Fine skeletal structures in Rugosa. Journal of the Faculty of Science, Hokkaido University. Series 4, Geology and Mineralogy 11: 571630.

Knoll, A.H., and W.W. Fischer. 2011. Skeletons and ocean chemistry: The long view. In Ocean Acidification, ed. J.-P. Gattuso and L. Hansson, 67-82. Oxford: Oxford University Press.

Krotow, P. 1888. Geologicheskiya izslyedovaniya na zapadnom sklonye Solidkamskago i Cherdynskogo Urala, Russia [Geological investigations on the western slope of the Urals in the regions of Tschedyn and Solikamsk]. Geologicheskogo Komieteta, Trudy [Transactions of the Geological Committee], 6: 563pp., 2 pls.

Mistiaen, B. 1984. Disparition des Stromatopores paléozoique ou survie du groupe: Hypothèse et discussion. Bulletin de la Société Géologique de France 26: 1245-1250.

Mistiaen, B. 1994. Skeletal density: Implications for development and extinction of Palaeozoic stromatoporoids. Courier Forschungsinstitut Senckenberg 172: 319-327 6 fig., appendix.

Muir, L.A., J.P. Botting, and M.A. Beresi. 2017. Lessons from the past: Sponges and the geological record. In Climate Change, Ocean Acidification and Sponges, ed. J.L. Carballo and J.J. Bell, 13-47. Springer International Publishing AG. https://doi.org/10.1007/978-3-319-59008-0_2.

Newell, N.D. 1935. Some mid-Pennsylvanian invertebrates from Kansas and Oklahoma: II. Stromatoporoidea, Anthozoa and Gastropoda. Journal of Paleontology 6: 341-355.

Ponomarenko, E.S., E.O. Statsenko, and M.N. Urazaeva. 2014. A hydrozoan interpretation of Palaeoaplysina (enigmatic organisms) based on the canal arrangement and structure. Paleontological Journal 48: 118-123.

Rigby, J.K., and D.J.C. Mundy. 2000. Lower Carboniferous sponges from the Craven Reef Belt, North Yorkshire. Proceedings of the Yorkshire Geological Society 53: 119-128.

Sandberg, P.A. 1983. An oscillating trend in Phanerozoic non-skeletal carbonate mineralogy. Nature 305: 19-22.

Schröder, S., and F. Soto. 2003. Lower Devonian (Emsian) rugose corals from the Cantabrian Mountains, northern Spain. Acta Palaeontologica Polonica 48: 547-558.

Smith, S. 1932. Labechia carbonaria, sp. nov., a Lower Carboniferous stromatoporoid from west Cumberland. Summary of Progress, Geological Survey of Great Britain and Museum of Practical Geology for 1931 2: 23$331 \mathrm{pl}$.

Sokolov, B.S. 1955. Tabulaty paleozoya Evropeiskoi chasti SSSR. Vvedenie: Obshchie voprosy sistematiki i istorii razvitiya tabulyat (s kharakteristikoi morfo- logicheski blizkikh grupp) [Paleozoic Tabulata of the European parts of the USSR: Introduction to the general study of the systematics and development of the tabulates]. Vsesoyuznogo Neftyanogo Nauchno- Issledovatel'skogo Geologo-Razvedochnogo Instituta (VNIGRI), Trudy, Leningrad (new series) 85: 527pp.

Stanley, S.M., and L.A. Hardie. 1998. Secular oscillations in the carbonate mineralogy of reef-building and sediment-producing organisms driven by tectonically forced shifts in seawater chemistry. Palaeogeography Palaeoclimatology Palaeoecology 144: 3-19.

Stearn, C.W. 2015a. Extinction patterns of the Paleozoic Stromatoporoidea. In Treatise on Invertebrate Paleontology. Part E (Revised), Porifera, vol 4-5, ed. P.A. Selden, 599-612. Lawrence: The University of Kansas Paleontological Institute liii +1223p., 665 fig. 42 tables.

Stearn, C.W. 2015b. Diversity trends of the Paleozoic Stromatoporoidea. In Treatise on Invertebrate Paleontology. Part E (Revised), Porifera, vol 4-5, ed. P.A. Selden, 593-597. Lawrence: The University of Kansas Paleontological Institute liii +1223p., 665 fig. 42 tables.

Stearn, C.W. 2015c. Microstructure and mineralogy of Paleozoic Stromatoporoidea. In Treatise on Invertebrate Paleontology. Part E (Revised), Porifera, vol 4-5, ed. P.A. Selden, 521-542. Lawrence: The University of Kansas Paleontological Institute liii +1223p., 665 fig. 42 tables.

Stearn, C.W., and C.W. Stock. 2015. A list of upper Palaeozoic-Mesozoic stromatoporoid-like genera; and excluded taxa. In Treatise on Invertebrate Paleontology. Part E (Revised), Porifera, vol 4-5, ed. P.A. Selden, 307-310. Lawrence: The University of Kansas Paleontological Institute liii +1223p., 665 fig. 42 tables.

Stock, C.W., H. Nestor, and B.D. Webby. 2015. Paleobiogeography of the Paleozoic Stromatoporoidea. In Treatise on Invertebrate Paleontology. Part E (Revised), Porifera, vol 4-5, ed. P.A. Selden, 653-689. Lawrence: The University of Kansas Paleontological Institute liii +1223p., 665 fig. 42 tables.

Vacelet, J. 1985. Coralline sponges and the evolution of Porifera. In The Origin and Relationships of the Lower Invertebrates, ed. S. Conway Morris, J.D. George, R. Gibson, and H.M. Platt, 1-13. Oxford: Clarendon Press.

Waters, C.N., R.A. Waters, W.J. Barclay, and J.R. Davies. 2009. A lithostratigraphical framework for the Carboniferous successions of southern Great Britain (Onshore). British Geological Survey Research Report, RR/09/01 ISBN 9780852726266.

Webb, G.E. 2002. Latest Devonian and early carboniferous reefs depressed reef building after the middle Paleozoic collapse. In Phanerozoic Reef Patterns, ed. W. Kiessling, E. Flügel, and J. Golonka, 239-270. Tulsa, Oklahoma: SEPM Special Publication No. 72.

Webby, B.D. 2015. Labechiida: Systematic descriptions. In Treatise on Invertebrate Paleontology. Part E (Revised), Porifera, vol 4-5, ed. P.A. Selden, 709-754. Lawrence: The University of Kansas Paleontological Institute liii +1223p., 665 fig. 42 tables.

West, R.R. 2011. Introduction to the fossil hypercalcified chaetetid-type Porifera (Demospongiae). Treatise Online, 20, part E, revised, volume 4, Chapter 2A.

West, R.R., and S. Kershaw. 1991. Chaetetid Habitats. In Fossil and Recent Sponges, ed. J. Reitner and H. Keupp, 445-455. Berlin: Springer-Verlag.

Wilson, E.C., R.H. Waines, and A.H. Coogan. 1963. A new species of Komia Korde and the systematic position of the genus. Palaeontology 6: 246253.

Wilson, J.L. 1975. Carbonate Facies in Geologic History, 471. New York Heidelberg, Berlin: Springer-Verlag.

Wood, R., J. Reitner, and R.R. West. 1989. Systematics and phylogenetic implications of the haplosclerid stromatoporoid Newellia mira nov. gen. Lethaia 22: 85-93.

Woodcock, N., and R. Strachan. 2012. Geological history of Britain and Ireland. 2nd ed, 442 pp. Oxford: Wiley-Blackwell. https://doi.org/10.1002/ 9781118274064.

Wulff, J. 2016. Sponge contributions to the geology and biology of reefs: Past, present, and future. In Coral Reefs at the Crossroads, Coral Reefs of the World 6, ed. D.K. Hubbard, C.S. Rogers, J.H. Lipps, and G.D. Stanley Jr., 103-126. Springer, 300 pp. https://doi.org/10.1007/978-94-017-7567-0 5.

\section{Publisher's Note}

Springer Nature remains neutral with regard to jurisdictional claims in published maps and institutional affiliations. 